\title{
Evaluation of the embryotoxicity in zebrafish (Danio rerio) of the flocculant and coagulant compounds used for water remediation
}

\author{
Avaliação da embriotoxicidade em zebrafish (Danio rerio) de compostos floculantes e
} coagulantes usados em remediação da água

Diego Sousa Moura ${ }^{1}$ (D), Rafael Oliveira Duarte da $\operatorname{Mota}^{2}$ (D), José Francisco Gonçalves Júnior²* (D),

\author{
Newton Flávio de Vasconcelos ${ }^{3}$ (D), Marco Aurélio Reis ${ }^{3}$ (D), Cesar Koppe Grisolia ${ }^{1}$
}

${ }^{1}$ Departamento de Genética e Morfologia, Instituto de Ciências Biológicas, Universidade de Brasília - UnB, Asa Norte, Campus Universitário Darcy Ribeiro, CEP 70910-900, Brasília, DF, Brasil

${ }^{2}$ Departamento de Ecologia, Instituto de Ciências Biológicas, Universidade de Brasília - UnB, Asa Norte, Campus Universitário Darcy Ribeiro, CEP 70910-900, Brasília, DF, Brasil

${ }^{3}$ WaterFlows Bioquimica do Brasil Company, Av. Pedro Botesi, 2636, Jardim Flamboyant, Mogi Mirim, SP, Brasil

*e-mail: jfjunior@unb.br

Cite as: Moura, D.S. et al. Evaluation of the embryotoxicity in zebrafish (Danio rerio) of the flocculant and coagulant compounds used for water remediation. Acta Limnologica Brasiliensia, 2019, vol. 31, e12.

Abstract: Aim: Leaching from mining activities reaches water bodies, causing water contamination and acidification by toxic metals. As a consequence, oxygen depletion occurs, with the disappearance of certain benthic organisms, losses in phytoplankton and zooplankton biomass, and fish mortality. Remediation of contaminated water from mining involves the use of flocculants based on acrylamide monomers and polyacrylamide and of coagulants based on aluminum. Our aim was to assess the aquatic toxicity of the flocculant WF 424 and the coagulant WF 2000 PCA. Methods: A flocculant anionic polymer (WF 424) and a coagulant polynuclear complex of polymerized hydro-aluminum ions (WF2000 PCA) were tested for embryotoxicity to zebrafish (Danio rerio, FET test - OEDC, 236, 2013). Results: After $96 \mathrm{~h}$ of exposure to WF424, there was no significant lethality, nor were there sublethal effects such as hatching delay, heartbeat alteration, and malformation in embryonic development, when compared with the control group ( $p>0.05$ ). The coagulant compound WF2000 PCA did not show lethal effects during $96 \mathrm{~h}$ of exposure, and EC50 was considered as above the highest concentration-level tested. Conclusions: For both compounds, no malformation, embryonic development delay or embryotoxicity were observed.

Keywords: mining tailing; contamination; wastewater; toxicity.

Resumo: Objetivo: $\mathrm{O}$ carreamento decorrente das atividades de mineração atinge corpos d'água, causando contaminação da água e acidificação por metais tóxicos. Como conseqüência, a depleção de oxigênio ocorre, com o desaparecimento de certos organismos bênticos, perdas na biomassa do fitoplâncton e do zooplâncton, e mortalidade de peixes. Remediação da água contaminada da mineraçáo envolve o uso de floculantes baseados em monômeros de acrilamida e poliacrilamida e de coagulantes à base de alumínio. Nosso objetivo foi avaliar a toxicidade aquática do floculante WF 424 e do coagulante WF 2000 PCA. Métodos: Um polímero aniónico floculante (WF 424) e um complexo polinuclear coagulante de íons hidro-alumínio polimerizados (WF2000 PCA) foram testados quanto à embriotoxicidade para o peixe-zebra (Danio rerio, teste FET - OEDC, 236, 2013). 
Resultados: Após 96 h de exposição ao WF424, não houve letalidade significativa, nem efeitos subletais como atraso na eclosão, alteração do batimento cardíaco e malformação no desenvolvimento embrionário, quando comparados com o grupo controle ( $p>0,05)$. O composto coagulante WF2000 PCA não apresentou efeitos letais durante 96 h de exposição, e EC50 foi considerado acima do nível de concentração mais alto testado. Conclusóes: Para ambos os compostos, nenhuma malformação, atraso no desenvolvimento embrionário ou embriotoxicidade foram observados.

Palavras-chaves: mineração de rejeito; contaminação; águas residuárias; toxicidade.

\section{Introduction}

Anthropogenic impacts on aquatic ecosystems are a current theme of significant importance due to the use of water resources for industrial, agricultural and urban processes (Dudgeon et al., 2006). This can lead to a reduction in water quality (Allan \& Castillo, 2007; Hepp \& Gonçalves Junior, 2015; Callisto et al., 2016), which affects fauna in their diversity and functionality by altering the key attributes of ecosystem integrity (Albuquerque et al., 2010; Honda \& Durigan, 2017; Dias, 2017).

The extraction and beneficiation of metals have produced different type of waste, causing serious risks to the aquatic environment. Leaching from mining processes reaches water bodies, causing water contamination and acidification by toxic metals (Wright \& Welbourn, 2002). Oxygen depletion and the disappearance of certain benthic organisms, decreases in phytoplankton and zooplankton biomass and changes in fish communities are indicators of water degradation caused by mining tailing. Remediation of wastewater from mining involves actions controlling the toxic load, significantly reducing contaminated sediments and allowing the restoration of aquatic biota (Wright \& Welbourn, 2002).

Flocculants based on acrylamide monomers and polyacrylamide are indicated for use in water remediation contaminated by mining tailings. They are used to promote the clumping of particles in surface water, so that this clump floats to the top. Coagulants based on aluminum are used to precipitate impurities in the water in a cleaning process. Both compounds are commonly used in the cleaning of drinking water, in sewage treatments and in the remediation of accidents caused by mining tailings or dam failure (Susaya et al., 2010; Wang et al., 2015). On the other hand, coagulation/flocculation treatment processes have showed an increased toxicity of treated waters (Wang et al., 2015).

WF424 is a flocculant anionic polymer, obtained from the copolymerization of acrylamide with acrylic acid or by hydrolysis reactions of polyacrylamide. Through a hydrolysis process, the amide group is replaced by a carboxylic group. In this way, the molecule acquires negative charge in a neutral or alkaline medium. The electrostatic repulsion between the ionized groups results in the stretching of the molecule. As a synthetic process, this macromolecule can be easily obtained as hydrolyzed monomers. Also, the hydrolysis and ionization processes to acquire the compound with desirable characteristics for the intended purpose are totally under control (AWWA, 2015, B453-13 Polyacrylamide).

WF2000 PCA $\left(\mathrm{Al}_{\mathrm{n}}(\mathrm{OH})_{\mathrm{m}} \mathrm{Cl}_{3 \mathrm{~m}-\mathrm{n}}\right)$ is a polynuclear complex of polymerized hydro-aluminum ions, with high solubility in water. Its hydrolysis provides the neutralization of electric charges in the medium and consequently promotes a more effective coagulation process when compared to the coagulants derived from monomeric salts. WF2000 PCA promotes the formation of clots by destabilizing colloidal systems in water, allowing sedimentation and consequently water clarification. The main advantages of its use in the treatment of water and effluents are related to better control of the $\mathrm{pH}$ of the medium, greater removal of organic and inorganic contaminants, reduction of sources of sulfate added to the treatment process and, especially, low levels of residual aluminum in the treated water, $0.01-0.05 \mathrm{mg} / \mathrm{L}$ (ABNT, 2016).

The study protocol for acute embryo-toxicity test (OECD, 2013), based on fertilized eggs of zebrafish (Danio rerio), has showed high sensitivity in the evaluation of chemical toxicity. For this reason, it was adopted by the European Union (EU 2010/63), as one of the main bioassays for the toxicological evaluation of chemical compounds for registration (REACH - Registration, Evaluation, Authorization and Restriction of Chemicals). There are few studies in the scientific literature showing the risks to the aquatic environment of such compounds used with the purpose of remediating water contaminated by mining tailings (Lammer et al., 2009; OECD, 2013). In this study, the zebrafish embryos were used in the understanding of the aquatic toxicity of the flocculant WF 424 and the coagulant WF 2000 PCA. 


\section{Materials and Methods}

\subsection{Chemicals tested}

The flocculant WF424 was obtained from WaterFlows Bioquímica do Brasil . CAS: 31212-13-2; poly(acrylic acid-co-acrylamide). Polyacrylamides (PAMs) belong to a large family of synthetic organic polyelectrolytes and, because of their high molecular weight, they make relatively dilute solutions of PAMs highly viscous. Some important physical and chemical characteristics are: High molecular weight relative to most other polymer types, between 4 and 30 million, $\mathrm{pH}$ in solution $0.5 \%$ weight between 4.0 and 9.0, and residual acrylamide monomer levels no greater than 0.05 percent by weight of the active polymer content (AWWA, 2015, B453-13 Polyacrylamide).

The coagulant WF 2000 PCA was obtained from WaterFlows Bioquímica do Brasil, CAS: 1327-41-9, with the empirical formula $\mathrm{Al}_{\mathrm{n}}(\mathrm{OH})_{\mathrm{m}} \mathrm{Cl}_{\mathrm{m}-\mathrm{n}}$. The polyaluminum chloride content is from 16 to 18 percent by weight expressed as $\mathrm{Al}_{2} \mathrm{O}_{3}$. The percent basicity of the sample can be calculated using the values of alkalinity $(\mathrm{OH} \%)$ and aluminum ( $\mathrm{Al} \%$ ), with 38 percent as the minimum concentration. Other important physical and chemical characteristics are: turbidity (NTU) less than $50, \mathrm{pH}$ in solution $1 \%$ in weight between 3.50 and 5.50 and density $\left(\mathrm{g} . \mathrm{cm}^{-3}\right)$ between 1.33 and 1.40 (AWWA, 2018, B408-18 Liquid polyaluminum chloride).

\subsection{Fish Embryo-toxicity Test (FET)}

Zebrafish were maintained in tanks with reverse osmosis and activated carbon filtered water and raised in an facility (ZebTec - Tecniplast, Varese, Italy) with a photoperiod cycle of 12:12h (light:dark) at the laboratory of Toxicologic Genetics at University of Brasilia (Brazil). The water parameters were strictly controlled: temperature was maintained at $27.0 \pm 1^{\circ} \mathrm{C}$, conductivity at $740 \pm 100 \mu \mathrm{S} / \mathrm{cm}, \mathrm{pH}$ at $7.0 \pm 0.5$ and dissolved oxygen $\geq 95 \%$ saturation. Zebrafish embryos were collected immediately after natural mating, rinsed in water, and checked under a stereomicroscope (Stereoscopic Zoom Microscope - Stemi 2000, Zeiss, Germany). The unfertilized eggs and those showing cleavage irregularities or injuries were discarded. Fish embryo toxicity test was based on the OECD guideline Protocol 236 "Fish Embryo Toxicity" (FET) test (OECD, 2013). Zebrafish embryos were exposed to seven graded concentrations of the WF2000 PCA, after $\mathrm{pH}$ adjustment for 7.2 with TRIS-buffer (Tris-Hydroxymethyl aminomethane CAS 77-86-1, tested alone at concentration of
$183 \mathrm{mg} / \mathrm{L})$ at levels of $0.0 ; 7.81 ; 15.62 ; 31.25$; $62.50 ; 125.0 ; 250.0$ and $500.0 \mathrm{mg} / \mathrm{L}$, prepared by successive dilutions of stock solution. WF424 was tested at concentration levels of $0.0 ; 1.0 ; 10.0$; 100.0 and $1000.0 \mathrm{mg} / \mathrm{L}$, also prepared by successive dilutions of stock solution at $\mathrm{pH}$ of 7.2. The test was performed using 60 eggs per treatment, divided in 3 replicates, selected and distributed in 24-well microplates in climate chamber (SL-24 Solab Científica, Brazil), 20 wells were filled with $2 \mathrm{~mL}$ of the test solution and four wells with water (internal plate control, as required in the OECD guideline). The test was initiated immediately after fertilization and continued for $96 \mathrm{~h}$. Embryos were observed daily under a stereomicroscope. Developmental parameters were evaluated in embryos over the test period using a magnification of $\times 70$ for eggs and $\times 40$ for hatched embryos. Before hatching, the following parameters were evaluated: egg coagulation, otolith formation, general delay in development, eye and body pigmentation, somites formation, heartbeat, edemas, detachment of the tail-bud from the yolk sac, yolk sac absorption and hatching. All parameters were assessed and quantified as observed or not observed. The FET-test with zebrafish embryos was approved by the Animal Ethics Committee of University of Brasilia, protocol n. 100226/2014.

\subsection{Statistical analyses}

A one-way ANOVA was used to detect the differences between the groups for normally distributed data sets. When data did not pass the Kolmogorov-Smirnov normality test and Levene's homogeneity of variance test, a Kruskal-Wallis test was performed. If significant results were found, either Dunnett's or Dunn's test (for parametric or non-parametric data, respectively) was used to detect significant differences between the tested concentrations and the control $(\mathrm{p}<0.05)$. All analyses were performed using the Sigma Stat 3.5 statistical package.

\section{Results}

During the 96 h of test, no significant mortality was observed for the control groups considering both treatment groups. Additionally, control groups showed normal development where the hatching rate and survival rates were above $90 \%$, as described by Kimmel et al. (1995) and recommended by the OECD 236 protocol.

After $96 \mathrm{~h}$ of exposure for WF424, there were no significant lethal (mortality) or sublethal effects such as hatching delay, heartbeat alteration 
and malformation in embryonic development, when compared with control group ( $p>0.05)$. The maximum mortality was $2 \%$ for the entire test period (Figure 1). In addition, the control group (water) presented normal development as described by Kimmel et al. (1995). The LC50 was estimated above the highest concentration tested $(1000 \mathrm{mg} / \mathrm{L})$. On the last day of exposure, it was observed that approximately $10 \%$ of the organisms exposed to the concentration of $1000 \mathrm{mg} / \mathrm{L}$ presented alteration in the balance (behavior change). However, there were no statistical differences when compared to the control group ( $\mathrm{p}>0.05)$.

An overview of the embryotoxicity test with the coagulant compound WF2000 PCA did not show lethal effects during $96 \mathrm{~h}$ of exposure (Figure 2).

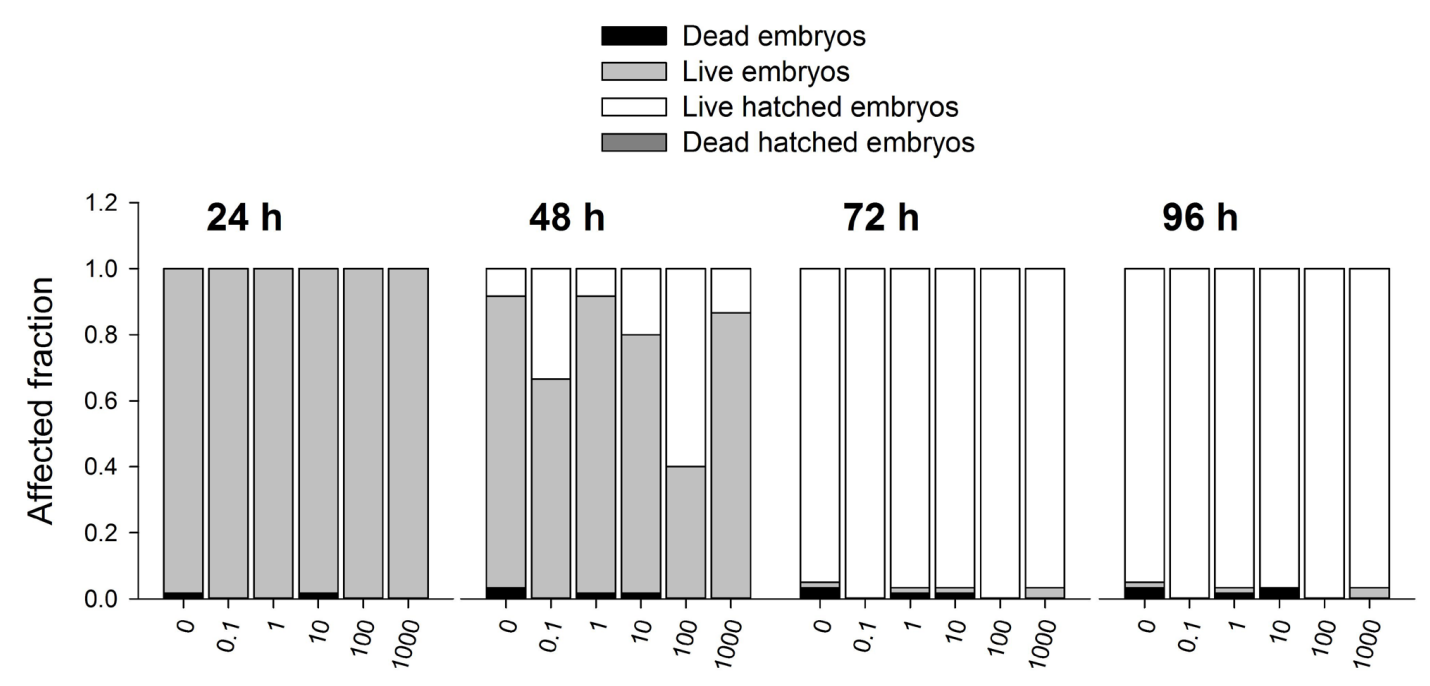

WF 424 (mg/L)

Figure 1. Overview of zebrafish embryo toxicity test after $96 \mathrm{~h}$ of exposure to WF424. The proportion of eggs and non-hatched embryos that died are represented by black bars; the proportion of embryos that stayed alive but did not hatch are presented as grey bars; those that hatched as white bars and the proportion of embryos that died after hatching as spotted, dark dashed grey bars.
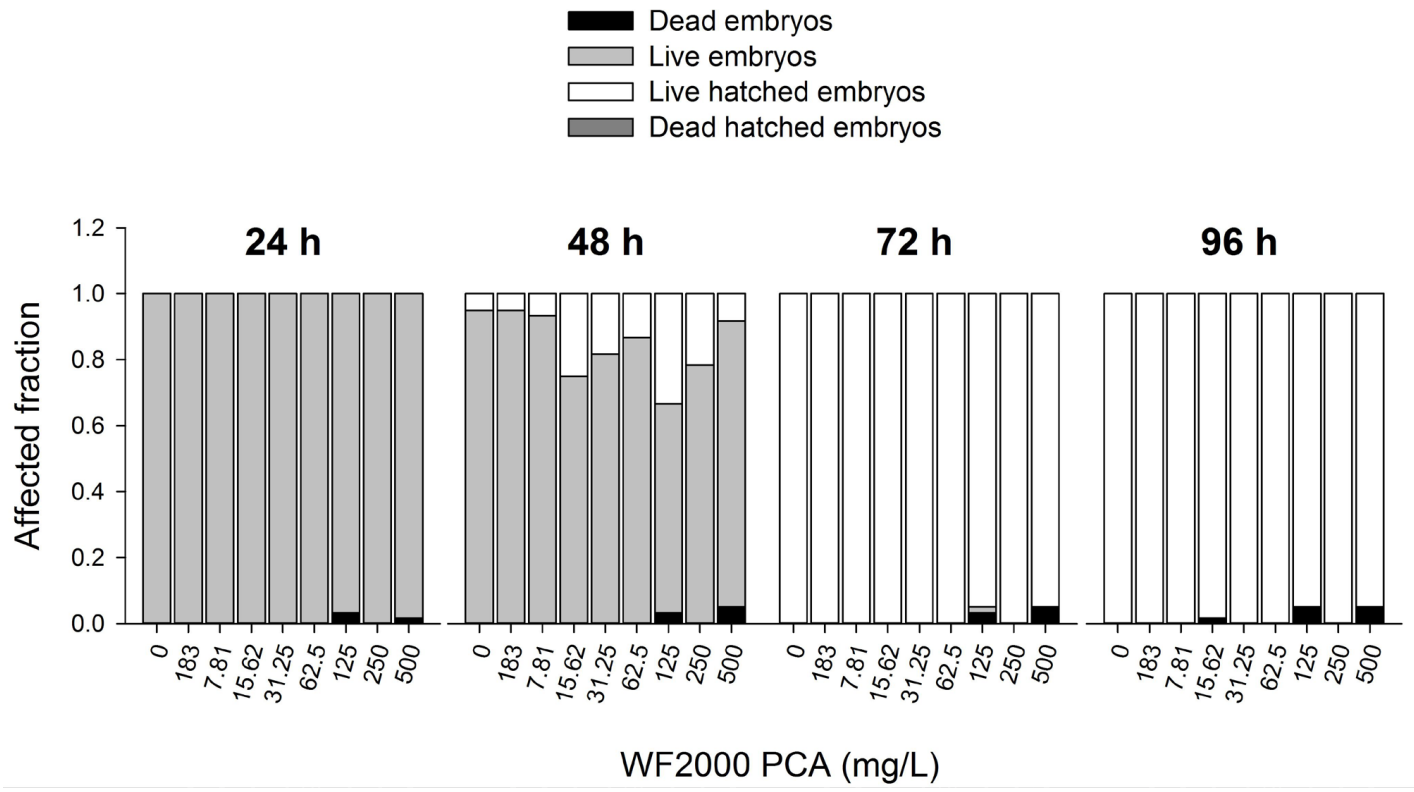

Figure 2. showing an overview of zebrafish embryo toxicity test after $96 \mathrm{~h}$ of exposure to WF 2000 PCA. The proportion of eggs and non-hatched embryos that died are represented by black bars; the proportion of embryos that stayed alive but did not hatch are presented as grey bars; those that hatched as white bars and the proportion of embryos that died after hatching as spotted, dark dashed grey bars. 
The LC50 was determined as being above the highest tested concentration levels of $500 \mathrm{mg} / \mathrm{L}$. It was not possible to determine the effective concentration (EC50) for any sublethal parameter analyzed, such as changes in balance, hatching, heartbeat and embryonic development. Therefore, EC50 was considered also as above the highest concentration level tested.

\section{Discussion}

The literature has shown that there are some sublethal and lethal effects of aluminum at different concentration ranges. García-Medina et al. (2010) studied the oxidative stress induced by aluminum in common carp lymphocytes (Cyprinus carpio), and they found significant effects at concentrations of $120-239 \mathrm{mg} / \mathrm{L}$. Griffitt (2018) studied the toxicological effects of metal nanoparticles of aluminum on zebrafish adults and juveniles, and they estimated a LC50 above $10 \mathrm{mg} / \mathrm{L}$. Lee (2014), when evaluating a zebrafish transgenic lineage (huORFZ), determined a LC90 of $34.53 \mathrm{mg} / \mathrm{L}$ for aluminum. Dave (1985) evaluated the influence of $\mathrm{pH}$ on aluminum toxicity, and determined a LC50 of 80-106 mg/L for zebrafish. In our results with WF 2000 PCA, the LC50 was estimated at over $500 \mathrm{mg} / \mathrm{L}$, which demonstrated low toxicological risks to the aquatic environment. Also, no malformation or developmental delay occurred in zebrafish embryos.

In a search in the database of the US Environmental Protection Agency using the keyword polyacrylamide, we did not find studies showing lethal and sublethal effects on aquatic organisms. Acharya et al. (2010) studied physiological responses in Daphnia magna exposed to Linear Anionic Polyacrylamide, in which they determined the acute LC50 at $152 \mathrm{mg} / \mathrm{L}$. In order to evaluate the acute toxicity of acrylamide to non-target organisms (macroinvertebrates and fish), through determination of LC50 values, Krautter et al. (1986) found: Daphnia magna $=160 \mathrm{mg} / \mathrm{L} ;$ Paratanytarsus parthenogenetica $=410 \mathrm{mg} / \mathrm{L}$; Salmo gairdneri $=110 \mathrm{mg} / \mathrm{L} ;$ Pimephales promelas $=120 \mathrm{mg} / \mathrm{L}$; Lepomis macrochirus $=100 \mathrm{mg} / \mathrm{L}$. Finally, Hall \& Mirenda (1991), evaluating the acute toxicity of 34 acrylamide polymers to Daphnia pulex and the fish Pimephales promela, observed that the chemical composition of the polymers is the main factor that controls the toxicity.

In addition, the molecular weight of the polymers should not be correlated with toxicity.
This makes it difficult to establish a toxicity pattern. Thus, specific studies are required for each molecule of interest. No studies were found with zebrafish (Danio rerio) for comparative purposes. The determination of the EC50 for sublethal measured parameters, such as changes in balance, hatching, heartbeat and embryonic development, was not possible due to the low toxicity of the tested compound. In fact, EC50 is also above the highest tested concentration. In conclusion, results of the embryotoxicity test showed that the flocculant compound WF 424 presented low acute toxicity to zebrafish embryos (Danio rerio). Thus, because the LC50 (mortality) and EC50 were above $1000 \mathrm{mg} / \mathrm{L}$, this compound does indeed represent a low risk to aquatic organisms. When compared with concentration ranges in the literature, the flocculant WF424 was tested at higher concentration levels than observed in other studies, and some toxicity occurred only at the highest exposure level of $1000 \mathrm{mg} / \mathrm{L}$, which does not occur in the remediation processes. The coagulant compound WF2000 PCA, with a LC50 over $500 \mathrm{mg} / \mathrm{L}$, also showed low risks to the environment. If used in accordance with the manufacturer's recommendations, neither compound causes damage to the aquatic environment.

In conclusion, these chemical compounds could have occasional toxicity at higher concentrations, differently from when used in the remediation of leaching from mining. These products can be considered as low toxicity to the zebrafish embryos. Once they can have commercial multiple uses, studies with species from different trophic levels should be carried out. Therefore, the management of the remediation processes must be under user control, especially when the water body receptor receives this effluent, and mainly when this water is used for human supply. The user must always be aware of the parameters established by the regulatory agencies. When working with remediators, we must always keep in mind the cost-benefit relationship for comparing the risks, human exposure and impacts on aquatic ecosystems.

\section{Acknowledgements}

This study was supported by the University of Brasilia, the Brazilian Research Council (CNPq, grant n. 305741/2015-2 and n. 310641/2017-9) and WaterFlows Bioquímica do Brasil. The authors declare that they have no conflict of interests. 


\section{References}

ACHARYA, K., SCHULMAN, C. and YOUNG, M.H. Physiological response of daphnia magna to linear anionic polyacrylamide: Ecological implications for receiving waters. Water, Air, and Soil Pollution, 2010, 212, 309-317.

ALBUQUERQUE, L. B., ALONSO, A.M., AQUINO, F.G., REATTO, A., SOUSA-SILVA, J.C., LIMA, G.E.F.W. \& SOUSA, E.D.S. Restauração ecológica de matas ripárias: uma questão de sustentabilidade. Planaltina: Embrapa, 2010. Embrapa Cerrados, no. 75 .

ALLAN, J.D. and CASTILLO, M.M. Stream ecology: structure and function of running waters. 2nd ed. Dordrecht: Springer, 2007.

AMERICAN WATER WORKS ASSOCIATION AWWA. B453-13 polyacrylamide. Denver: AWWA, 2015.

AMERICAN WATER WORKS ASSOCIATION AWWA. B408-18 liquid polyaluminum chloride. Denver: AWWA, 2018.

ASSOCIAÇÃO BRASILEIRA DE NORMAS TÉCNICAS - ABNT. NBR 16488 - polyaluminum chloride $(P A C)-2016$. Drinking water and wastewater treatment purposes - Technical especification, sampling and test methods. Rio de Janeiro: ABNT, 2016.

CALLISTO, M., GONÇALVES, J.F. and LIGEIRO, $\mathrm{R}$. Water resources in the rupestrian grasslands of the espinhaço mountains. In: G. W. FERNANDES, editor. Ecology and conservation of mountaintop grasslands in Brazil. Cham: Springer International Publishing, 2016, pp. 87-102.

DAVE, G. The Influence of $\mathrm{pH}$ on the Toxicity of aluminum, cadmium, and iron to eggs and larvae of the Zebrafish, Brachydanio rerio. Ecotoxicology and Environmental Safety, 1985, 10, 253-267.

DIAS, B. Biodiversidade, porque importa! Revista Cause, 2017, 5, 94-100.

DUDGEON, D., ARTHINGTON, A.H., GESSNER, M.O., KAWABATA, Z., KNOWLER, D.J., LEVEQUE, C., NAIMAN, R.J., PRIEURRICHARD, A.H., SOTO, D., STIASSNY, M.L. and SULLIVAN, C.A. Freshwater biodiversity: importance, threats, status and conservation challenges. Biological Reviews of the Cambridge Philosophical Society, 2006, 81, 163-182.

EUROPEAN UNION - EU. Directive 2010/63/EU of the European Parliament of the Council of 22 September 2010 on the protection of animals used for scientific purposes. Official Journal of the European Union, Strasbourg, 22 sep. 2010, pp. L 276/33-L $276 / 79$.

GARCÍA-MEDINA, S., RAZO-ESTRADA, A.C., GÓMEZ-OLIVÁN, L.M., AMAYA-CHÁVEZ, A., MADRIGAL-BUJAIDAR, E. and GALAR-
MARTÍNEZ, M. Aluminum-induced oxidative stress in lymphocytes of common carp Cyprinus carpio. Fish Physiology and Biochemistry, 2010, 36(4), 875-882. http://dx.doi.org/10.1007/s10695-0099363-1. PMid:19866366.

GRIFFITT, R.J. Effects of particle composition and species on toxicity of metallic nanomaterials in aquatic organisms. Environmental Toxicology and Chemistry, 2018, 27, 1972-1978.

HALL, W.S. and MIRENDA, R.J. Acute toxicity of wastewater treatment polymers to Daphnia pulex and the fathead minnow (Pimephales promelas) and the effects of humic acid on polymer toxicity. Research Journal of the Water Pollution Control Federation, 1991, 63, 895-899.

HEPP, L.U. and GONÇALVES JUNIOR, J.F. A decomposição de detritos em riachos como serviço ecossistêmico de regulação e suporte prestado pela natureza. In: L. M. PARRON, R. GARCIA JUNIOR, E. B. OLIVEIRA, G. G. BROWN, R. B. PRADO, org. Serviços ambientais em sistemas agricolas e florestais do bioma Mata Atlântica. Brasília: EMBRAPA, 2015, pp. 226-233. vol. 3.

HONDA, E.A. and DURIGAN, G. A restauração de ecossistemas e a produção de água. Hoehnea, 2017, 44, 315-327.

KIMMEL, C.B., BALLARD, W.W., KIMMEL, S.R., ULMAN, B. and SCHILLING, T.F. Stages of embryonic development of the zebrafish. Developmental Dynamics, 1995, 203, 253-310.

KRAUTTER, G.R., MAST, R.W., ALEXANDER, H.C., WOLF, C.H., FRIEDMAN, M.A., KOSCHIER, F.J. and THOMPSON, C.M. Acute toxicity tests with acrylamide monomer and macroinvertebrates and fish. Environmental Toxicology and Chemistry, 1986, 5(4), 373-377. http://dx.doi.org/10.1002/ etc. 5620050406 .

LAMMER, E., CARR, G.J., WENDLER, K., RAWLINGS, J.M., BELANGER, S.E. and BRAUNBECK, T. Is the fish embryo toxicity test (FET) with the zebrafish (Danio rerio) a potential alternative for the fish acute toxicity test? Comp. Biochem. Physiol. Part C Toxicol. Pharmacol., 2009, 149, 196-209.

LEE, H.-C. Zebrafish transgenic line is an effective living bioindicator for detecting environmental toxicants. PLoS One, 2014, 9(3), e90160. http://dx.doi. org/10.1371/journal.pone.0090160.

ORGANIZAÇÃO PARA A COOPERAÇÃO E DESENVOLVIMENTO ECONÓMICO -OECD. Test no. 236: Fish Embryo Acute Toxicity Test (FET). Paris: OECD, 2013, 22 p.

SUSAYA, J., KIM, K.-H. and JUNG, M.C. The impact of mining activities in alteration of ss levels in the surrounding ecosystems: an encompassing risk assessment and evaluation of remediation strategies. Journal of Hazardous Materials, 2010, 182, 427-438. 
WANG, C., ALPATOVA, A., MCPHEDRAN, K.N. and GAMAL EL-DIN, M. Coagulation/ flocculation process with polyaluminum chloride for the remediation of oil sands process-affected water: performance and mechanism study. Journal of Environmental Management, 2015, 160(1), 254-262. http://dx.doi.org/10.1016/j.jenvman.2015.06.025. PMid:26119332.
WRIGHT, D.A. and WELBOURN, P. Environmental toxicology. Cambridge: Cambridge University Press, 2002. Recovery, rehabilitation, and reclamation, pp. 520-535. https://doi.org/10.1017/ CBO9780511805998.

Received: 09 December 2018 Accepted: 08 March 2019 